\title{
Examination of Job Satisfaction of the Medical Vocational High School Teachers
}

\author{
Hatice Vatansever Bayraktar ${ }^{1}$, Burcu Güney ${ }^{2}$ \\ ${ }^{1}$ Asist. Prof. Dr., İstanbul Sabahattin Zaim University, Education Faculty, İstanbul, Turkey \\ ${ }^{2}$ Medical Vocational High School Teacher, Ministry of Education, İstanbul, Turkey \\ Correspondence: Asist. Prof. Dr. Hatice Vatansever Bayraktar, İstanbul Sabahattin Zaim University, Education Faculty, \\ İstanbul, Turkey
}

Received: December 10, 2015 Accepted: February 14, 2016 Online Published: February 21, 2016

doi:10.11114/jets.v4i4.1242

URL: http://dx.doi.org/10.11114/jets.v4i4.1242

\begin{abstract}
The aim of this study is to determine the job satisfaction level of Medical Vocational High School teachers and whether it differs according to different variables. The research was organized in accordance with the screening model. The population of the research was composed of vocational course teachers who worked in Medical Vocational High Schools providing training in Istanbul in the 2013-2014 academic year. Sample was composed of 144 vocational course teachers chosen from 12 schools which were determined by the simple random cluster sampling method from within the general population. Personal Information Form developed by the researcher was used to determine the demographic characteristics of the group. Hackman and Oldham Job Satisfaction Scale, which was developed by Hackman and Oldham (1980) and which was adapted to Turkish by Silah (2002), was used to determine the job satisfaction level of the vocational course teachers at Medical Vocational High School. Job satisfactions of teachers constituting the sample group were observed to be medium-level. This also showed that the job satisfactions of medical vocational course teachers were at instability level. Teachers did not experience the feeling of high or low job satisfaction; they experienced the feeling of a medium level of job satisfaction. No statistically significant difference was observed among the arithmetic averages of the groups by the type of school they worked, gender, age, marital status, seniority and the residence status of teachers' job satisfaction.
\end{abstract}

Keywords: medical vocational high school, medical vocational high school teacher, job satisfaction

\section{Introduction}

Happiness a worker feels or emotional satisfaction a worker achieves as a result of personal assessment of his/her business or work life is called as job satisfaction (Akçamete, Kaner and Sucuoğlu, 2001). According to another definition, job satisfaction means the worker's happiness which is obtained by pecuniary advantages acquired from working and by a work created by the worker with his/her friends by doing an enjoyable business (Akınc1, 2002). Job satisfaction is an emotional reaction which is a component of the difference between the worker's demands on the nature of business and the worker's thoughts about the level of providing the acquisition of these in the business environment (Balc1, 2002). According to Tengilimoğlu (2005), job satisfaction is "the difference between what employees expect from the business environment and working environment and what they perceive from the business environment and working environment. Meeting the expectations of employees on the one hand increases the job satisfaction, on the other hand means the realization of corporate goals more efficiently."

Job satisfaction is positive affective states. These sensations reflect the feelings of the individual to a particular situation and object. These are positive feelings. When compared the relationship between job satisfaction and personal factors such as rewards, fees, the work itself, supervision and team work, the relationship between job satisfaction and personal factors also revealed the tendency to remain in the organization (Celep, 2000).

The relationship between satisfaction and motivation is in the form of mutual interaction. The fact that a person has achieved satisfaction means that the environment needed for him/her to be motivated has been prepared. Because an individual with satisfaction is in a quite appropriate condition to change and motivate his/her behavior. Also, a motivated person can taste and enjoy the inner peace a result of all his/her studies. In other words, motivation can 
provide satisfaction. Furthermore, we shouldn't be surprised by the fact that certain situations and feelings have both effects at the same time (Eroğlu, 1995).

Job satisfaction is defined as an emotional orientation of worker for the job role that he/she currently has or an emotional reaction to work he/she shows. According to another definition, job satisfaction is a sense of pleasure that a worker achieves as a result of assessing his/her work or occupational life. The more this sense of pleasure that the worker achieved is high, the more job satisfaction that he/she achieved from his/her work will be high. On the other hand, dissatisfaction is a sign indicating that the employee is not satisfied with the reward policy or organizational development level of the organization. It is noted that the worker's feelings of deprivation or insufficient reward and motivation policy will create dissatisfaction and will strengthen the tendencies to change business organization. As a result, it is seen that commitment is obviously different from the job satisfaction. In this context, organizational commitment is the belief in the organization, and job satisfaction is a response to certain business tasks and experiences (Balay, 2000). An employee, who loves his/her institution and stays in the organization for a long time, knows the organizational objectives well and continues to work according to corporate culture.

When analyzed the social and cultural environment in which the individual lives, it is understood that he/she is affected by many feelings and value judgments. When considered from this perspective, fields providing satisfaction are too many to count (Çalışkan, 2005). In education, management function is important. Managers must determine common goals together with their employees to achieve the determined targets. By preparing positive conditions, they appreciate the works and development, efforts made and development. They resolve the problems they faced in a flexible management approach by facing them and stating clearly what they want. They care about the communication climate in order to be successful in influencing people and communicating with them. They take a step toward excellence in management with a trust and warm relations mutually created, care about the value of quality to provide superior service and ideally carry out the management of the plans through which they can realize the service models to be able to follow (Çağlayan, 2002).

While it was believed that high job satisfaction caused higher productivity in the past, however then, researches showed that this assumption was not true. Satisfied employees can be engaged in production at high, medium or low level. Satisfaction-productivity relationship is a complex relationship which is affected by the rewards received by the worker, and many other variables. Some correlations were found between success and job satisfaction. However, they are small and insignificant. Also, there is a problem about whether job satisfaction leads to success or whether success leads to job satisfaction (Tikici et al, 1998: 51). People's desires and needs may be different. Therefore, each teacher wants to attract special attention proprietarily. A management of high quality would be achieved by the prearrangement of the changes to be made and the ideas to be implemented, by making the necessary changes with a participatory approach and by including the knowledge and skills of all employees (Çağlayan, 2002).

Another concept, which is closely related with satisfaction and the product of satisfaction, is morale. Morale is an attitude which makes the worker willing to work for the purposes of the organization and which ensures him/her keep working. Although it is a product of satisfaction, there are two aspects that separate morale from satisfaction (Başaran, 1982): "While satisfaction is for the past and current situation, morale is mainly for the future. Satisfaction is based on an individual feeling and the individual's own self-respect, however, morale is based on being together, getting involved in the group and obtaining common purpose within the organization."

Job satisfaction is correlated with labour turnover. Workers with lower job satisfaction are likely to look for other jobs by leaving their jobs. This is also true for absenteeism. If job satisfaction is low, then the possibilities of workers' absenteeism or late arrival to work will increase (Günbay1, 2000). Job satisfaction will increase the time spent at work. In this case, individuals providing job satisfaction will make greater contributions to the organization.

Being unable to be satisfied with the work is the decrease in the pleasure of individual he/she obtains from work, and the discomfort on individual caused by this situation. A wide variety worker issues are tried to be explained by job dissatisfaction (Özday1, 1990). While job satisfaction has positive results on the worker and organization, likewise, job dissatisfaction has also negative results on these. As a result of the dissatisfaction of workers, negative consequences occur for the organization such as absenteeism, arriving late for work, quitting the job, not obeying the rules of discipline, occupational accidents, alienation and going on strike if they are member to a trade union.

Many factors may have effects on job satisfaction. These factors can be categorized as environmental (the work itself and the working environment), psychological (personality, behavior, attitude) and demographic (age, gender) factors (Crossman and Haris, 2006).

In the study of Gergin (2006) aimed at determining the general job satisfaction levels of teachers working in official public primary schools and the factors affecting these job satisfaction levels; teachers' perceptions about the job and its nature, the level of job, working conditions, inspection, wages, management, promotion opportunities, interpersonal 
relationships and school environment and the dimensions of school-family relationships were analyzed according to variables of branch, length of service, education, gender, marital status. When the results were analyzed in general, it was seen that the dimension that teachers achieved the job satisfaction at the highest level was the "job and its nature" according to the perceptions of teachers participated in the research. However, 'inspection, wages and school-family relationships' were the dimensions in which the job satisfaction perception was the lowest. In dimensions of 'the level of job and management', the job satisfaction level perceived by teachers can be considered as high. Also, teachers who participated in the research found the dimensions of "working conditions, promotion opportunities, interpersonal relationships and school environment' sufficient at medium level.

In the literature, many variables thought to have effects on satisfaction in the teaching profession are encountered. Variables such as wages, promotion and development opportunities, the structure of the school in which they work, the atmosphere of the class in which they carry on education and training activities, the duration they spend in the profession, student behaviors, genders, colleagues, social needs and teachers' level of education are included in the studies.

A healthy person uses and develops his/her capacity by working and producing something and achieves pleasure and satisfaction from this. Therefore, we see that also the people who do not need money to live acquire a profession and work, and that some people prefer a profession that brings little income to a profession that can provide more income. Therefore, profession is seen as the way of using the capacity and self-realization beyond earning money (Kuzgun, 2000). The fact that teaching has a labor-intensive characteristic requires teachers to achieve satisfaction from their profession in some sense. Because a teacher who achieves satisfaction from his/her profession will be in a continuous development in order to be helpful towards his/her school, himself/herself, class and the students in the class. It is greatly possible that teachers can cope with the difficulties and obstacles that they will face in the profession by achieving professional satisfaction. As a result of the data obtained from 1134 teachers in the doctorate study of Özday1 (1990) in which the teachers' job satisfaction and stress were compared, it was observed that the factors affecting the job satisfaction levels of teachers working in public and private high schools were similar, that the job satisfaction levels of teachers working in public high schools were lower compared to teachers working in private high schools, and that the job stresses of teachers working in public high schools were higher.

If all members of the school are able to act together to improve the institution of which they are member, then that culture is a powerful culture. It can be said that strong organizational culture has many benefits. For example, it gives the common identity and sense of belonging to the members of the organization, ensures cohesion and integration, ensures productivity and effectiveness, gives meaning to working life, facilitates the solution of organizational problems and the realization of the organization's mission becomes easier (Celep, 2000). It can be said that if a behavior to be shown to be the learner ends up with a satisfaction that will meet the needs of the person, frequency of performing the behavior increases. This is also possible through having the capabilities required by the professional activities. Therefore, it can be said that there is a relationship between the level of capability and job satisfaction, arising from the success. Job satisfaction is not a simple function of the level of job and the individual's level of capability. On the contrary, job satisfaction emerges as a situation dependent on the interaction between the necessities of the position and the skills of the person like general satisfaction (Kuzgun, 2000).

Administrators should know that people are different from each other. One of two teachers is not the same as the others; they differ from each other in terms of behavior. It may not always be possible to distinguish these differences among people. Therefore, an administrator should have accumulation of knowledge for the recognition of human, observation and evaluation, and all administrators should be a little psychologist; these determinations should be benefited in the expansion of school, in training students and in achieving the objectives of the program. When an administrator recognizes the people he/she works with well and increases his/her ability to appreciate, then he/she will recognize that it will not be much easier to give authority to the employees and to increase the efficiency of the school (Çağlayan, 2002). The solution of these problems or minimizing the adverse effects is concealed in the establishment of effective communication and organizational commitment.

Previous research on the subject includes Taşdan and Tiryaki (2008), Yılmaz (2012), Buluç and Demir (2015), Şahin (2013), Sarpkaya (2000), Bozkurt and Bozkurt (2008), Can and Dalaman (2010), Akın and Koçak (2007). They investigated the subject on the following topics: comparison of the job satisfaction levels of private and public elementary school teachers, job satisfaction levels of primary school teachers, relationship between the self-efficacy perceptions and job satisfactions of primary and secondary school teachers, job satisfaction levels of official primary school teachers, job satisfaction of teachers working in high schools, internal factors affecting the job satisfaction in education sector, relationship between job satisfaction levels of classroom teachers and the monthly income status, salary and the adequateness of tools and equipments, relationship between the classroom management skills and job 
satisfaction levels of teachers. The significance of the present study is that it will contribute to the previous literature by examining the job satisfaction levels of Medical Vocational High School teachers.

The aim of this study is to determine the job satisfaction levels of Medical Vocational High School teachers and whether teachers' job satisfactions differ according to the variables of type of school in which they work, gender, age, marital status and the statuses of seniority and residence.

\section{Method}

\subsection{Model of the Research}

The aim of this study is to determine the job satisfaction level of Medical Vocational High School teachers and whether it differs according to different variables. Research was organized in accordance with the screening model. Karasar (2002) defines screening models as research approaches aiming to describe a situation which is in the past or is currently existing as is.

\subsection{Population and Sample}

The population of the research was composed of vocational course teachers who worked in Medical Vocational High Schools providing training in Istanbul in 2013-2014 academic year.

Sample was composed of 144 vocational course teachers chosen from 12 schools which were determined by the simple random cluster sampling method from within this general population.

\subsection{Data Collection Tools}

Personal Information Form developed by the researcher was used to determine the demographic characteristics of the group. Hackman and Oldham Job Satisfaction Scale, which was developed by Hackman and Oldham (1980) and which was adapted to Turkish by Silah (2002), was used to determine the job satisfaction level of the vocational course teachers at Medical Vocational High School.

The scale which was prepared by Hackman and Oldham (1980) in order to reveal the assessments of people about their job, was composed of 14 items and arranged according to Likert technique (Akt: Izgar, 2003). The reliability and validity study was carried out by Hackman and Oldham (1980) through test- retest method; and the point average was observed to be 34,27 in the first application, and the point average was observed to be 34,71 in the first application. The fact that the average points of two applications were too close was evaluated as an indicator of the reliability of the scale (Akt: Güler, 1990).

\subsection{Analysis of Data}

Arithmetic average and standard deviation values were used in order to determine the job satisfaction levels of vocational course teachers at Medical Vocational High School. The state of whether the job satisfaction levels of teachers differed according to variables such as the type of school where they worked, gender and marital status was analyzed by Mann Whitney U Test; the state of whether it differed according to the variables of age and residence was analyzed by Kruskall Wallis $\mathrm{H}$ test; the state of whether it differed according to the variable of seniority was analyzed by ANOVA test.

\section{Results}

\subsection{Comparison of Teachers' Job Satisfaction Levels and Socio-demographic Variables}

Analysis results of the job satisfaction levels of vocational course teachers at medical vocational high schools in terms of the demographic variables of school type, gender, age, marital status and the statuses of service and residence where there is enough distribution are shown below.

Table 1. Job Satisfaction Levels of Teachers

\begin{tabular}{lcccccc}
\hline Dimension & $\mathrm{n}$ & Lowest value & Highest value & $\overline{\mathrm{x}}$ & ss & $\begin{array}{c}\text { Number of } \\
\text { item }\end{array}$ \\
\hline Full scale & 144 & 20 & 67 & 46,33 & 9,03 & 14 \\
\hline
\end{tabular}

As it is seen in Table 1, it was observed that the arithmetic average of teachers' job satisfaction scale total points was $=46,33$, standard deviation was ss $=9,03$, the lowest point received was 20 and the highest point received was 67 . When taking this value obtained into consideration, it was seen that teachers' job satisfaction was at medium-level. This also means that the job satisfactions of those with whom the questionnaire was carried out were at instability level.

\subsection{Teachers' Job Satisfaction Levels According to Type of School They Work}


Teachers' job satisfaction levels according to type of school they work are given in table 2.

Table 2. Mann Whitney U-Test Table between Teachers' Job Satisfactions and the Variable of Type of School They Work

\begin{tabular}{llrrrrrr}
\hline Point & Group & $N$ & $\bar{x}_{\text {sira }}$ & $\begin{array}{c}\text { Sum of } \\
\text { lines }\end{array}$ & $U$ & $z$ & $p$ \\
\hline \multirow{2}{*}{ Job } & Public & 126 & 73,00 & 9198,50 & & & \\
Satisfaction & Private & 18 & 68,97 & 1241,50 & 1070,500 &,- 384 &, 701 \\
& Total & 144 & & & & &
\end{tabular}

When analyzed Table 2, no statistically significant difference was observed between the arithmetic averages of the groups as a result of the Mann Whitney-U test which was carried out to determine whether teachers' job satisfactions showed a significant difference according to the type of school they worked ( $\mathrm{p}>.05)$.

\subsection{Teachers' Job Satisfaction Levels According to Gender}

Teachers' job satisfaction levels according to gender are given in Table 3.

Table 3. Mann Whitney U-Test Table between Teachers' Job Satisfaction Levels and the Variable of Gender

\begin{tabular}{llrrrrrr}
\hline Point & Group & $N$ & $\bar{x}_{\text {sira }}$ & $\begin{array}{c}\text { Sum of } \\
\text { lines }\end{array}$ & $U$ & $z$ & $p$ \\
\hline \multirow{2}{*}{$\begin{array}{l}\text { Job } \\
\text { Satisfaction }\end{array}$} & Female & 125 & 73,40 & 9175,00 & & & \\
& Male & 19 & 66,58 & 1265,00 & 1075,000 &,- 665 &, 506 \\
& Total & 144 & & & & & \\
\hline
\end{tabular}

When analyzed Table 3, no statistically significant difference was observed between the arithmetic averages of the groups as a result of the Mann Whitney-U test which was carried out to determine whether teachers' job satisfactions showed a significant difference according to gender ( $>$.05).

\subsection{Teachers' Job Satisfaction Levels According to Age}

Teachers' job satisfaction levels according to age are given in Table 4.

Table 4. Kruskal-Wallis H-Test Table between Teachers' Job Satisfaction Levels and the Variable of Age

\begin{tabular}{llrrrr}
\hline Point & Age & $N$ & $\bar{x}_{\text {sira }}$ & $\mathcal{X}$ & $p$ \\
\hline \multirow{3}{*}{ Job Satisfaction } & 22-30 years & 18 & 63,58 & & \\
& 31-40 years & 47 & 67,95 & & \multirow{2}{*}{,300 } \\
& 41 years and above & 79 & 77,24 & & \\
& Total & 144 & & & \\
\hline
\end{tabular}

When analyzed Table 4, no statistically significant difference was observed between the arithmetic averages of the groups as a result of the Kruskal Wallis-H test which was carried out to determine whether teachers' job satisfactions showed a significant difference according to age ( $\mathrm{p}>.05)$.

\subsection{Teachers' Job Satisfaction Levels According to Marital Status}

Teachers' job satisfaction levels according to marital status are given in Table 5.

Table 5. Mann Whitney-U Test Table between Teachers' Job Satisfaction Levels and the Variable of Marital Status

\begin{tabular}{lllccccc}
\hline Point & \multicolumn{1}{c}{ Group } & $N$ & $\bar{x}_{\text {sira }}$ & $\begin{array}{c}\text { Sum of } \\
\text { lines }\end{array}$ & $U$ & $z$ & $p$ \\
\hline \multirow{2}{*}{$\begin{array}{l}\text { Job } \\
\text { Satisfaction }\end{array}$} & Single & 28 & 70,66 & 1978,50 & & & \\
& Married & 116 & 72,94 & 8461,50 & 1572,500 &,- 260 &, 795 \\
& Total & 144 & & & & & \\
\hline
\end{tabular}

When analyzed Table 5, no statistically significant difference was observed between the arithmetic averages of the groups as a result of the Mann Whitney-U test which was carried out to determine whether teachers' job satisfactions showed a significant difference according to marital status ( $p>.05)$. 


\subsection{Teachers' Job Satisfaction Levels According to Seniority Status}

Teachers' job satisfaction levels according to seniority status are given in Table 6.

Table 6. ANOVA Analysis Table between Teachers' Job Satisfactions and the Variable of Seniority

\begin{tabular}{|c|c|c|c|c|c|c|c|}
\hline Groups & $\mathrm{N}$ & $\overline{\mathrm{X}}$ & SS & Sum of Squares & $\mathrm{sd}$ & $\mathrm{F}$ & $\mathrm{p}$ \\
\hline $0--5$ years & 39 & 46,64 & 8,725 Intra-groups & 252,950 & 2 & & \\
\hline $6-15$ years & 36 & 44,08 & 8,136 Intergroups & 11412,710 & 141 & 1,563 & ,213 \\
\hline 16 years and above & 69 & 47,32 & 9,551 Total & 11665,660 & 143 & & \\
\hline Total & 144 & 46,33 & 9,032 & & & & \\
\hline $0--5$ years & 39 & 46,64 & 8,725 & & & & \\
\hline
\end{tabular}

When analyzed Table 6, no statistically significant difference was observed between the arithmetic averages of the groups as a result of one-way analysis of variance (ANOVA) which was carried out to determine whether teachers' job satisfactions showed a significant difference according to seniority status ( $>$ >.05).

\subsection{Teachers' Job Satisfaction Levels According to Residence Status}

Teachers' job satisfaction levels according to residence are given in Table 7.

Table 7. Kruskal Wallis-H Test Table between Teachers' Job Satisfactions and the Variable of Residence

\begin{tabular}{|c|c|c|c|c|c|}
\hline Point & Residence & $N$ & $\bar{x}_{\text {sira }}$ & $x$ & $p$ \\
\hline \multirow{4}{*}{ Job Satisfaction } & Own house & 73 & 72,64 & \multirow{4}{*}{,110 } & \multirow{4}{*}{,946 } \\
\hline & Rental & 54 & 71,44 & & \\
\hline & Public Housing & 17 & 75,26 & & \\
\hline & Total & 144 & & & \\
\hline
\end{tabular}

When analyzed Table 7, no statistically significant difference was observed between the arithmetic averages of the groups as a result of the Kruskal Wallis-H test which was carried out to determine whether teachers' job satisfactions showed a significant difference according to residences ( $p>.05)$.

\section{Discussion, Conclusion and Recommendations}

The following conclusions are achieved in accordance with the data obtained in this study carried out to determine the job satisfaction levels of Medical Vocational High School teachers and to whether these differed according to different variables:

It was observed that the job satisfactions of teachers constituting the sample group were at medium level. This also showed that the job satisfactions of medical vocational course teachers were at instability level. Teachers did not experience the feeling of high or low job satisfaction; they experienced the feeling of a medium level of job satisfaction. Without doubt the level of job satisfaction of theachers depends on many factors and it is very likely that these factors have varying weights on different teachers.

As a result of the research, no statistically significant difference was observed between the arithmetic averages of the groups and the job satisfactions of teachers according to the type of school they worked, no statistically significant difference was observed between the arithmetic averages of the groups and the job satisfactions of teachers according to gender, no statistically significant difference was observed between the arithmetic averages of the groups and the job satisfactions of teachers according to age, no statistically significant difference was observed between the arithmetic averages of the groups and the job satisfactions of teachers according to marital status and no statistically significant difference was observed between the arithmetic averages of the groups and the job satisfactions of teachers according to seniority.

In the present study it is is observed that the job satisfactions of teachers constituting the sample group were at medium level. The result of the researches carried out by Altınkurt and Y1lmaz (2014); Y1lmaz (2012); Günbayı and Tokel (2012); Buluç and Demir (2015) supported this finding.

According to results obtained from the research carried out by Altınkurt and Y1lmaz (2014), teachers had medium level job satisfaction.

According to the result of the research carried out by Y1lmaz (2012), job satisfaction levels of primary school teachers were at medium level. 
As a result of the research carried out by Günbayı and Tokel (2012), teachers' job satisfactions were observed to be at "medium" level in factors of "Student and teacher qualifications" and "working conditions" according to the teachers' job satisfaction averages.

As a result of the research titled "Relationship between the Self-Efficacy Perceptions and Job Satisfactions of Primary and Secondary School Teachers" which was carried out by Buluç and Demir (2015), the general average of teachers' opinions for job satisfaction scale was at "medium" level.

The results of other studies carried out in this field which were different from our research are mentioned below:

The study titled "Job Satisfaction Levels of Teachers" carried out by Şahin (2013) was performed on 343 teachers working in official primary schools within the boundaries of Konak district of Izmir Province. As a result of the research, the general job satisfactions of teachers were observed to be at "partially satisfied" level.

As a result of the study titled "Job Satisfaction of Teachers Working in High Schools: Sample of Manisa Province" carried out by Sarpkaya (2000), teachers' job satisfactions were observed to be low.

In a research carried out by Şahin (1999), the general job satisfaction levels of teachers were observed to be at partial level.

As a result of the research carried out by Can, Can and Dalaman (2010), the job satisfaction levels of classroom teachers varied between normal and high job satisfaction, and there was no Classroom Teacher in low job satisfaction.

The aim of the research carried out by Taşdan and Tiryaki (2008) was to compare the job satisfaction levels of private and public elementary school teachers. Job satisfaction levels of private primary school teachers were observed to be high in the whole scale and in its sub-dimensions.

In the study carried out by Akın and Koçak (2007), a low level of significant relationship in the positive direction was observed between the classroom management skills and job satisfaction levels of teachers.

As a result of the research, no statistically significant difference was observed between the arithmetic averages of the groups and the job satisfactions of teachers according to the type of school they worked.

In the literature, it was seen that researches carried out on this topic gave different results. In his study in which the job satisfaction of teachers working in public and private schools were compared, Genç (2006) observed that the external job satisfaction levels of teachers working in private schools were higher than teachers working in public schools although there was not a significant difference between the internal satisfaction points of teachers working in public and private schools.

Sönmezer and Eryaman (2008) examined whether there was a significant difference between the job satisfaction of teachers working in public and private educational institutions. As a result, it was observed that there was a significant difference between the job satisfactions of teachers working in private educational institutions and the job satisfactions of teachers working in public schools in favor of those who worked in private educational institutions.

As a result of the research, no statistically significant difference was observed between the arithmetic averages of the groups and the job satisfactions of teachers according to gender.

The result of the researches carried out by Taşdan and Tiryaki (2008); Koç et al (2009); Y1lmaz (2012); Ertürk and Keçecioğlu (2012); Kılıç (2011) supported this finding.

The results of other studies carried out in this field which were different from our research are mentioned below:

According to the result of the research carried out by Tunacan and Çetin (2009), female teacher's satisfaction that she achieved from professional reputation was higher compared to male teacher.

As a result of the research carried out by Yüksel and Yüksel (2014), it was observed that the job satisfaction point averages of male teachers were higher than the point averages of female teachers.

As a result of the research, no statistically significant difference was observed between the arithmetic averages of the groups and the job satisfactions of teachers according to age.

The result of the researches carried out by Karaköse and Kocabaş (2006); Şahin and Dursun (2009); Tunacan and Çetin (2009); Yılmaz (2012); Koç et al (2009); Sarpkaya (2000); Şahin (2013); Ertürk and Keçecioğlu (2012); Yüksel and Yüksel (2014); Şahin (1999); Şahin and Dursun (2009) supported this finding.

As a result of the research, no statistically significant difference was observed between the arithmetic averages of the groups and the job satisfactions of teachers according to marital status.

The result of the researches carried out by Koç et al (2009); Sarpkaya (2000); Ertürk and Keçecioğlu (2012); Kılıç (2011); Şahin and Dursun (2009) supported this finding. 
As a result of the research, no statistically significant difference was observed between the arithmetic averages of the groups and the job satisfactions of teachers according to seniority.

The result of the researches carried out by Taşdan and Tiryaki (2008); Sarpkaya (2000); Yılmaz (2012); Şahin and Dursun (2009) supported this finding.

As a result of the research, no statistically significant difference was observed between the arithmetic averages of the groups and the job satisfactions of teachers according to residence status.

The following recommendations are made in accordance with the findings obtained as a result of the research.

It should be ensured that teachers choose the profession willing fully, and their level of efficiency and job satisfaction should be increased.

It may be recommended that necessary measures should be taken to improve the social and economic conditions by increasing the status of teaching profession in the society. The measures should be taken by Ministry of Education, Provincial and District Directorate of National Education and administrators in order to increase the teachers' job satisfactions. Improvements can be made on issues such as the existing rights of teachers etc. in accordance with the suggestions of teachers by carrying out employee satisfaction questionnaire etc. In this case, it is possible to increase the teachers' job satisfaction.

This study involves the vocational course teachers working in medical vocational high schools in Istanbul. Similar studies can be carried out with a larger sample group (in the manner that will involve teachers working in different provinces and other branch teachers).

The relationship between motivational resources and job satisfaction can be investigated in new studies to be carried out on this topic.

\section{References}

Akçamete, G., Kaner, S., \& Sucuoğlu, B. (2001). Öğretmenlerde Tükenmişlik, İş Doyumu ve Kişilik, Ankara: Nobel Yayıncilik.

Akın, U., \& Koçak, R. (2007). Öğretmenlerin Sınıf Yönetimi Becerileri ile İş Doyumları Arasındaki İlişki, Kuram ve Uygulamada Eğitim Yönetimi, Sayı 51, 353-370

Akıncı, Z. (2002). Turizm Sektöründe İşgören İş Tatminini Etkileyen Faktörler: Beş Yıldızlı Konaklama İşletmelerinde Bir Uygulama, Akdeniz I.I. B.F. Dergisi, (4), 1-25.

Altınkurt, Y., \& Yılmaz, K. (2014). Öğretmenlerin Mesleki Profesyonelliği ile İş Doyumları Arasındaki İlişki, Sakarya University Journal of Education, 4/2, 57-71

Balay, R. (2000). Yönetici ve Öğretmenlerde Örgütsel Bağlllık, Ankara: Nobel Yayıncılık.

Balcı, A. (2002). Örgütsel Gelişme. Ankara: Pegem A Yayıncılık.

Başaran, İ. E. (1982). Örgütsel Davranış, Ankara: A. Ü. Eğitim Fakültesi Yayınları, No:108

Bozkurt, Ö., \& Bozkurt, İ. (2008). İş Tatminini Etkileyen İşletme İçi Faktörlerin Eğitim Sektörü Açısından Değerlendirilmesine Yönelik Bir Alan Araştırılması, Doğuş Üniversitesi Dergisi, 9(11), 1-18.

Buluç, B., \& Demir, S. (2015). İlk ve Ortaokul Öğretmenlerinin Öz-Yeterlik Algıları ile İş Doyumları Arasındaki İlişki, Ahi Evran Üniversitesi Kırşehir Eğitim Fakültesi Dergisi (KEFAD), 16(1), 289-308

Çağlayan, A. (2002). İlköğretimlerde Eğitimde Yönetim ve Yönetimde Kalite, İstanbul: Bilge Yayıncıllk.

Çalışkan, Z. (2005). İş Tatmini: Malatya'da Sağlık Kuruluşları Üzerine Bir Uygulama Doğu Anadolu Bölgesi Araştırmaları; İnönü Üniversitesi Sağlık Yüksek Okulu - Malatya.

Can, S., Can, Ş., \& Dalaman, O. (2010). Sınıf Öğretmenlerinin Çeşitli Faktörlere Göre İş Doyum Düzeyleri (Muğla İli Örneği), Selçuk Üniversitesi Ahmet Keleşoğlu Eğitim Fakültesi Dergisi, 30, 299-311.

Celep, C. (2000). Eğitimde Örgütsel Adanma ve Öğretmenler, Ankara: Anı Yayınc1lık.15-140.

Crossman, A., \& Haris, P. (2006). Job Satisfaction of Secondary School Teachers. Educational Management Administration and Leadership, 34, 29-46. http://dx.doi.org/10.1177/1741143206059538

Eroğlu, F. (1995). Davranış Bilimleri. İstanbul: Beta Basın Yayım Dağıtım A.Ş.

Ertürk, E., \& Keçecioğlu, T. (2012). Çalışanların İş Doyumları ile Mesleki Tükenmişlik Düzeyleri Arasındaki İlişkiler: Öğretmenler Üzerine Örnek Bir Uygulama, Ege Akademik Bakış Dergisi, 12(1), 39-52.

Genç, M. (2006). Özel ve Devlet Okulu Öğretmenlerinin İş Doyum Düzeylerinin Karşılaştırılması, Yayımlanmamış 
Yüksek Lisans Tezi, Yeditepe Üniversitesi, Sosyal Bilimler Enstitüsü, İstanbul.

Gergin, B. (2006). İlköğretim Okulu Öğretmenlerinin İş Doyum Düzeyleri (Çorum İli Örneği), Yayınlanmamış Yüksek Lisans Tezi, Gazi Üniversitesi, Eğitim Bilimleri Enstitüsü, Ankara.

Güler, M. (1990). Endüstri İşletmelerinin İş Doyumu ve Depresyon, Kaygı ve Diğer Bazı Değişkenlerin Etkisi, Yayınlanmamış Doktora Tezi, Hacettepe Üniversitesi, Ankara.

Günbayı, İ. (2000). Örgütlerde İs Doyumu ve Güdüleme. Ankara: Özen Yayıncılık.

Günbayı, İ., \& Tokel, A. (2012). İlköğretim Okulu Öğretmenlerinin İş Doyumu ve İş Stresi Düzeylerinin Karşılaştırmalı Analizi, ODÜ Sosyal Bilimler Enstitüsü, Sosyal Bilimler Araştırmaları Dergisi, 3(5), 77-95.

Izgar, H. (2003). Endüstri ve Örgüt Psikolojisi, Eğitim Kitapevi Yayınları, Konya.

Karaköse, T., \& Kocabaş, İ. (2006). Özel ve Devlet Okullarında Öğretmenlerin Beklentilerinin İş Doyumu ve Motivasyon Üzerine Etkileri, Eğitimde Kuram ve Uygulama, 2(1), 3-14.

Karasar, N. (2002). Bilimsel Araştırma Yöntemleri, Ankara: Nobel Yayınları

Kılıç, Ö. S. (2011). İlköğretim Okullarında Görev Yapan Okul Müdürü ve Öğretmenlerin İş Doyumu (Tokat İli Örneği), Yayınlanmamış Yüksek Lisans Tezi, Selçuk Üniversitesi, Eğitim Bilimleri Enstitüsü, Konya

Koç, H., Yazıcıoğlu, İ., \& Hatipoğlu, H. (2009). Öğretmenlerin İş Doyum Algıları ile Performansları Arasındaki İlişkinin Belirlenmesine Yönelik Bir Araştırma, Ondokuz Mayıs Üniversitesi Eğitim Fakültesi Dergisi, 28, 13-22.

Kuzgun, Y. (2000). Meslek Danışmanlı̆̆ı Kuramlar ve Uygulamalar, Nobel Yayın Dağıtım, Ankara.

Özdayı, N. (1990). Resmi ve Özel Liselerde Çalışan Öğretmenlerin İş Tatmini ve İş Streslerinin Karşılaştırmalı Analizi, Yayınlanmamış Doktora Tezi, İstanbul Üniversitesi, Sosyal Bilimler Enstitüsü, İstanbul.

Şahin, H., \& Dursun, A. (2009). Okul Öncesi Öğretmenlerinin İş Doyumları: Burdur Örneği, Mehmet Akif Ersoy Üniversitesi Eğitim Fakültesi Dergisi, 9(18), 160-174.

Şahin, İ. (1999). Illköğretim Okullarında Görevli Öğretmenlerin İs Doyum Düzeyleri, Yayınlanmamış Yüksek Lisans Tezi, Dokuz Eylül Üniversitesi, Eğitim Bilimleri Enstitüsü, İzmir.

Şahin, İ. (2013). Öğretmenlerin İş Doyumu Düzeyleri, YYÜ Eğitim Fakültesi Dergisi, X(I), 142-167.

Sarpkaya, R. (2000). Liselerde Çalışan Öğretmenlerin İş Doyumu: Manisa İli Örneği, Amme İdaresi Dergisi, 33(3), 111-124.

Silah, M. (2002). Sanayi İşletmelerinde Önemli ve Çağdaş Bir Gereksinim: Süreç Danışmanlığı Uygulamaları. Çukurova Üniversitesi Sosyal Bilimler Dergisi, 26(1), 143-168.

Sönmezer, M. G., \& Eryaman, M. Y. (2008). Kamu ve Özel Eğitim Kurumlarında Çalışan Öğretmenlerin İş Tatmin Düzeylerinin Karşılaştırılması, Eğitimde Kuram ve Uygulama, 4(2), 189-212.

Taşdan, M., \& Tiryaki, E. (2008). Özel ve Devlet İlköğretim Okulu Öğretmenlerinin İş Doyumu Düzeylerinin Karşılaştırılması, Eğitim ve Bilim, 33(147), 54-70.

Tengilimoğlu, D. (2005). "Kamu Ve Özel Sektör Örgütlerinde Liderlik Davranışı Özelliklerinin Belirlenmesine Yönelik Bir Alan Çalı̧̧ması" Elektronik Sosyal Bilimler Dergisi, 4(14), 1-16.

Tunacan, S., \& Çetin, C. (2009). Lise Öğretmenlerinin İş Doyumunu Etkileyen Faktörlerin Tespitine İlişkin Bir Araştırma, M.Ü. Atatürk Eğitim Fakültesi Ĕ̈itim Bilimleri Dergisi, 29, 155-172.

Yılmaz, K. (2012). İlköğretim Okulu Öğretmenlerinin İş Doyumu Düzeyleri ile Örgütsel Vatandaşlık Davranışları Arasındaki İlişki. Anadolu Journal of Educational Sciences International, 2(2), 1-14.

Yüksel, H., \& Yüksel, M. (2014). İş Doyumu ile İşten Ayrılma Düzeyi Arasındaki İlişki: İlköğretim Öğretmenleri Üzerinde Bir Uygulama, Uluslararası Sosyal Araştırmalar Dergisi, 7(32), 559-572. 